\title{
Musical and Language Proficiency of Students Majoring in Singing
}

\author{
Veronika BocsI \\ bocsiveron@gmail.com \\ (University of Debrecen Faculty of Child and Adult Education, \\ Hajdúböszörmény, Hungary)
}

Andrea Ujvarosi

novandra14@gmail.com

(University of Debrecen Faculty of Music, Debrecen, Hungary)

Received: 28.10.2017; Accepted: 30.11.2017

Abstract: The aim of our study is to give an overview about language and musical skills of students in musical traning courses and we try to outline the effects of the sociocultural background in these fields. We would like to show the main patterns of language proficiency (the number of langugages they speak and levels of the language skills) and we also analyse the efficiency of language learning. The institutional language courses and the practices of interpretation in the original language will be analysed as well. Our questionnare was used in this analysis in the spring of 2017. Students from six higher educational institutions were the respondents. The number of the respondents was 90 and from the answers a database was created with the help of SPSS 19 Programme. Percents, means and chi-square statistics were used. We have verified our hypothesis which refers to the effects of students' sociocultural background because these variables (parental education, economic capital, type of the settlement) have formed the chances and forms of the music learning (e.g. the starting date of learning music) and language skills. If we analyse the patterns of the language proficiency the central position of the English is obvious, but this pattern is not in line with the expectations of singing in the original language because the main body of vocal literature is composed in Italian, French, Russian and German. In our opinion this gap should be covered by the institutions as well and these requirements should be incorporated in the curricula.

Keywords: languge skills, musical skills, students, higher education 


\section{Introduction}

In our days opera theatres put clear requirements from their singers to be able to interpret vocal works in the original language. The Hungarian practice of the original language performances have been through a long developmental route during the last decades due to its historical and educational traditions. Now it is out of question that the singing text only in the original language can interpret the intention of the composer faithfully. Linguistic efficiency - along with music education -is necessarily an attribute of a soloist. In our study, we first review what the sociocultural facts are and how they influence the musical and linguistic efficiency of soloist students in today's Hungarian higher education system. Then, we will see which langauges they study with their level of efficiency and in what framework. Last, we will explore how linguistic trainings relate to the requirements of interpretation in foreign languages.

\section{Theoretical frames}

In Hungarian higher education Music and Musical Art mediation trainings are traditionally separated from each other vigorously. In connection with the training of soloists - depending on the aim of qualifying as a teacher or a music artist - there is a great diversity in training levels and forms. The artistic training of soloists with the original content of the word takes place in the Liszt Ferenc Academy of Music and in the faculties of once colleges, in Debrecen, Pécs, Szeged, Miskolc and Győr. The Bologna Treaty with its uniform European Higher Education Area brought the home introduction of the Anglo-saxon higher education system. In the multi-cycle training system started in 2007, soloist students can take part in three years of Solo singing in BA level or two years of Opera-, Oratorio and Lied singing in MA level. The main form of Musical Art mediation has become the teachers' undivided training programme introduced in 2012 in the Art education as well (Duffek, 2009). In the artist training, the soloist student takes solo singing as a main subject that gives the backbone of his studies. Besides singing studies, the following subjects give the fullness of the artist training: Vocal Practice, Chamber singing, Song literature, Repetiteur training, History of Opera and Songs, Acoustics, Stage moving and Elocution. As in the professional level the excellence of the language is as much important as the voice (Owen, 1960), there is a special need of linguistic training in the background for the interpretations of the original languages making up most of the vocal works of literature: Italian, French, German, English, Russian and Spanish. Besides foreign language lessons there are lessons of role playing in foreign languages and foreign language interpretation courses as optional studies in the curricula nets of the several institutitons with various names and number of lessons in every institution. 


\section{Methodology}

We carried out our research with the help of a questionnaire for the students and elaborated them with quantitative technique. The variety pattern of the students' query was given by the soloist students of the Liszt Ferenc Academy of Music, the University of Debrecen Faculty of Music, the University of Szeged Faculty of Music, the University of Pécs Faculty of Music and Virtual Arts, the University of Széchenyi István Faculty of Art, the Instutute of Musical Art and the University of Miskolc Bartók Béla Institute for Music. $(\mathrm{N}=90)$ From the anonymous respondants we generated an SPSS database and used the SPSS 19 program for the analysis. During our analysis we made percents and averages from the economic capital indicators and created indices from the linguistic efficiency and number of language exams.

\section{Empirical findings}

As a first step of our quantitative analysis we review the demographical and sociocultural attributes of the students taking part in the questionnare research. Wherever we can we compare our data with national or regional ones. As the number of elements of the database is low, we mostly used percentage distributions and averages.

The sample shows the following distribution of genders: $24,7 \%$ of the respondants are men, 75,3\% are women. The rate of women, as we can see, is higher than the national average that is $51,6 /$ according to the $\mathrm{KSH}$ (Central Statistical Office) in the term of 2016/17. (I1) In the background the reason can be the higher participation of women in the artistic trainings in higher education in general as well. The average age of the respondants is 25,4 years old, the minimum value being 19 years old, the maximum is 59 years old. Soloist singing in higher education does not necessarily connect to secondary musical studies, so therefore, in many cases, graduation from grammar school, many years of preparation or even getting a degree in a different direction can prelude studies of singing in higher education. This can be the reason for a higher age rate than the average and the extension of the age of the students. Another explanatory fact is the introduction of the Bologna treaty that challanged artists and teachers who were already working in the field to try getting their Master's degree in their adulthood.

According to the type of settlement the greatest groups are made up by the metropolitans (29\%) and the dwellers of county seats $(29,5 \%)$. The smallest group comes from villages and farms (14\%) and there were $28 \%$ coming form smaller towns. This distribution shows a significant difference in percentages from the students' vice sample of the 2012 Hungarian Youth national database. In the whole of higher education, students' distribution is less polarized than in our sample; there is a greater rate of students coming from villages and smaller towns $(26,1 \%$ and 37,2\%) represented in the population of students (Bocsi et al., 2017). We can explain this shift by the fact that the infrastructural background of musical training is less developed in the villages, farms and smaller 
settlements and the institutional conditions of musical studies are met mostly in the towns and the capital. ${ }^{1}$

Our next step was to inspect the educational qualification of the parents of the students. We have got a remarkable result showing that both with fathers and mothers the biggest group is made up by parents who have college or university qualifications. (The value is 53,9 with mothers and 38,2 with fathers.) On the other hand, the Eurostudent V. pattern shows a dominance of secondary qualification, 33\% of the fathers and $39,1 \%$ of mothers have degrees (Garai and Kiss, 2014). Among the soloist students those coming from a family with higher status are overrepresented. There is only $4,5 \%$ of mothers and $2,2 \%$ of fathers with elementary qualifications (Figure 1.)

Figure 1. Educational qualifications of parents of soloist students (Foreign Language Interpretation Database, given in percentages, $\mathrm{N}=90$ )

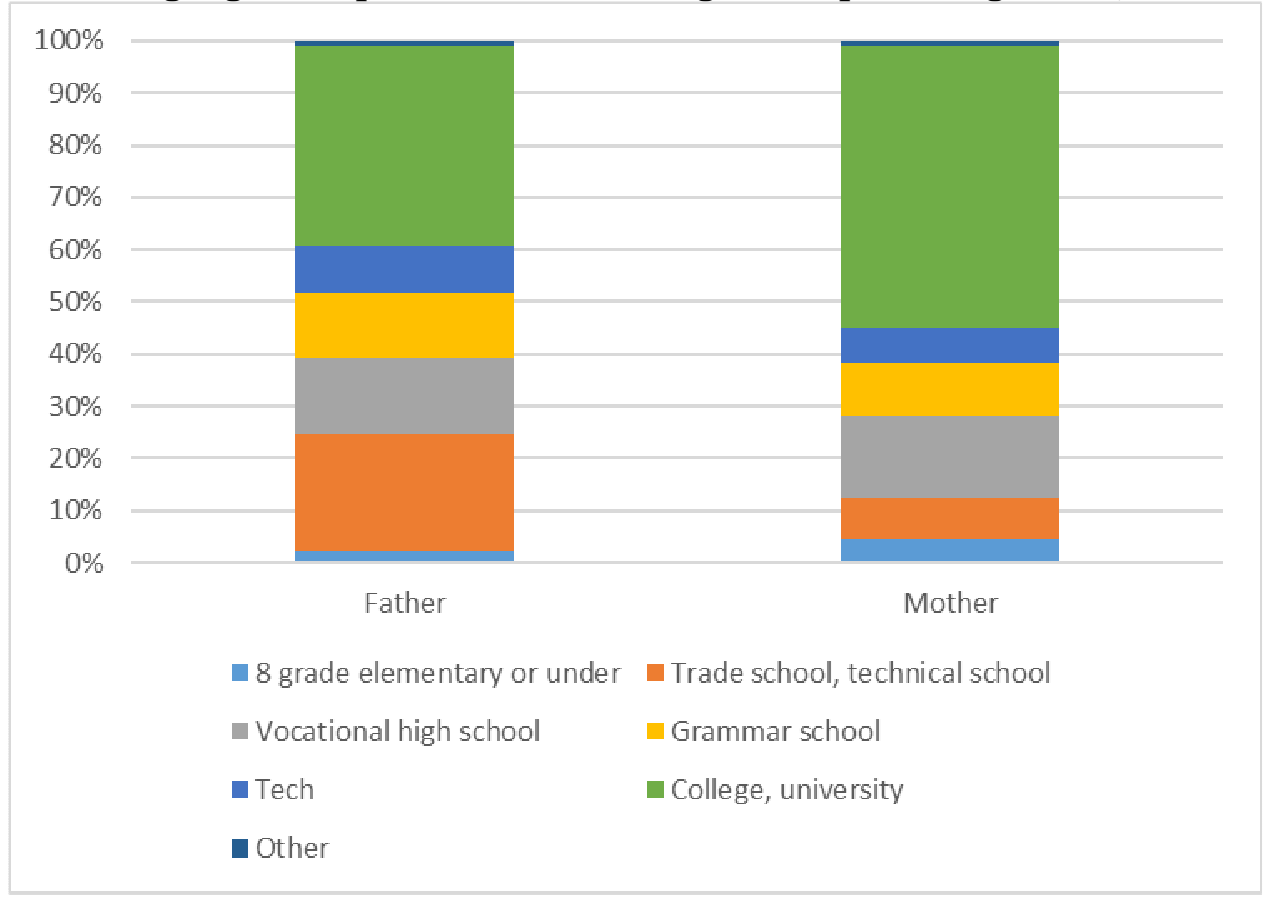

Figure 2. is to show the distributions according to levels and majors. You can see that most of the respondants take part in the soloist BA level training. In accordance with the student distribution, the fewest students were MA Oratorio and Song and MA teacher's training students taking part in the research. In the distribution of majors and levels you can see the training system of the above mentioned inspected institutions reflected. In the Liszt Ferenc Academy of Music, there is no undivided teachers' training programme, and the University of Szeged Faculty of

\footnotetext{
${ }^{1}$ During our analysis we created an index from non-perishable consumer goods, but we will use it only later since our set of questions were not identical with other researches. This set of questions cntained 10 of the non-perishable consumer goods (house/apartment, summer house, car, washing machine, dryer, AC, television, personal computer, smart phone and tablet/laptop). We indicated 2 points for the answer 'I have more of these' and 1 point for 'I have one of these' answer and o point if the student did not have any of these goods. In a later section of our reearch we grouped the students to about 33\% groups (students with low, medium and high economic capital vice-sample) and that is how we made the comparisons.
} 
Music and the University of Miskolc Bartók Béla Institute for Music do not have artistic training. In all of the inspected institutions there is BA level training, which is why there is a high rate of students taking BA level training among the respondants.

Figure 2. Distribution of majors and training levels among the respondants of the Foreign Language Interpretation Questionnare (Foreign Language Interpretation Database, given in percentages, $\mathrm{N}=90$ )

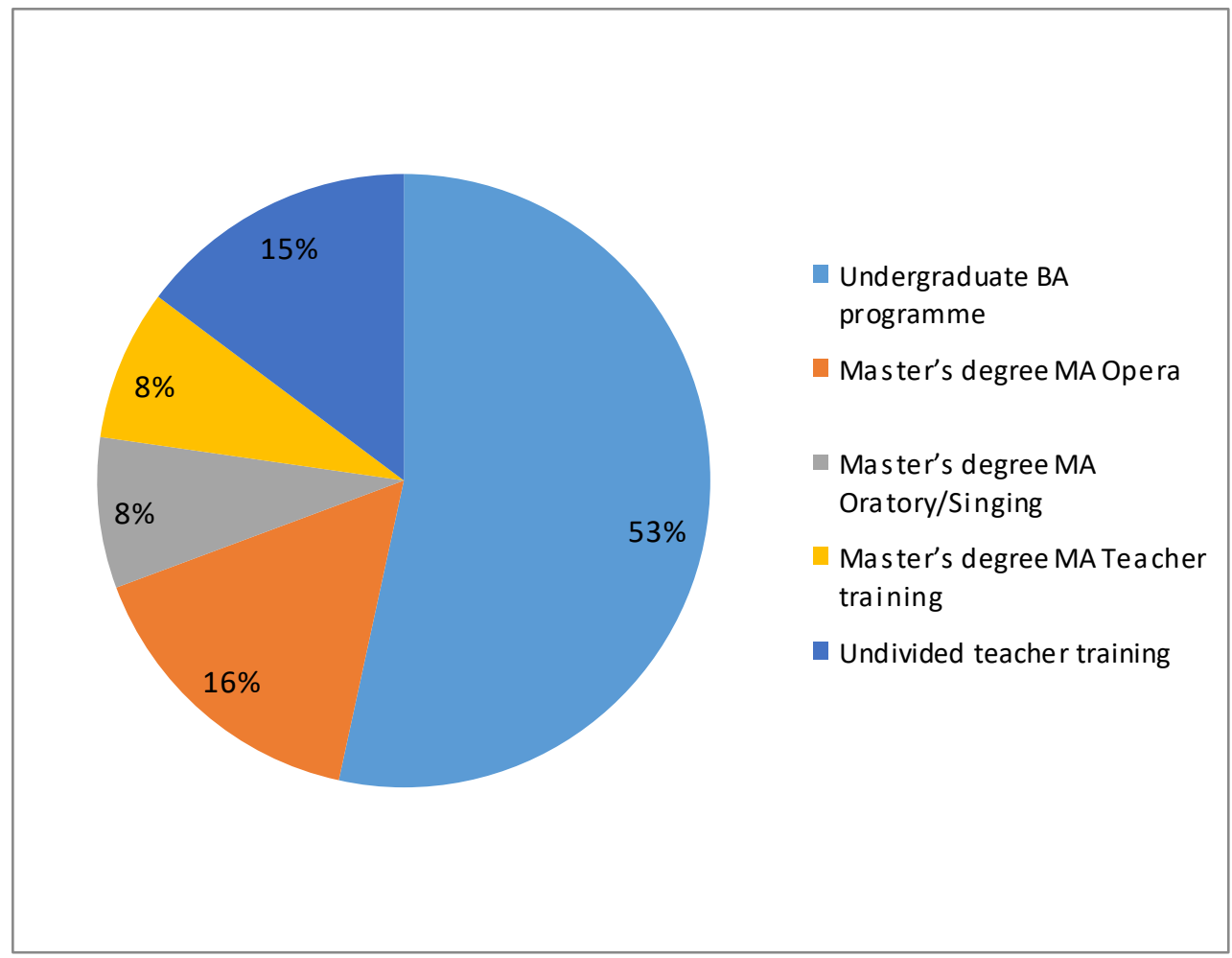

\section{Music Education}

For a thorough approach to professional efficiency we find it necessary to examine the beginnings, directions and methods of music learning. The beginning of music learning is 8,8 years old as an average, however, the soonest start at the age of 3 and latest start at the age of 27 show a very extreme result. We think that the explanation is again about the fact that the desire to learn music appears only when one becomes an adult or in the middle of adulthood.

We think it is important to know the chosen musical instruments and the beginning of learning since these facts had significance when examining the educators' component. As you can see in Figure 3. the most preferred instrument is the piano that was marked the first instrument by 40 students. We got 11 violins, 8 flutes, $6-6$ cellos and singing, 5 flageolets, 2 guitars and a joint start of piano and singing studies from 2 students. Organ, percussion instruments and contrabass as a first instrument appears with 1 student respectively. The preference of string instruments in the choice of soloist students can be well-observed that support the well- 
foundedness of 'legato' singing and the music technical demonstration of the use of string instruments.

Figure 3. Starting instruments in music learning (Foreign Language Interpretation Database, given in capita $\mathrm{N}=90$ )

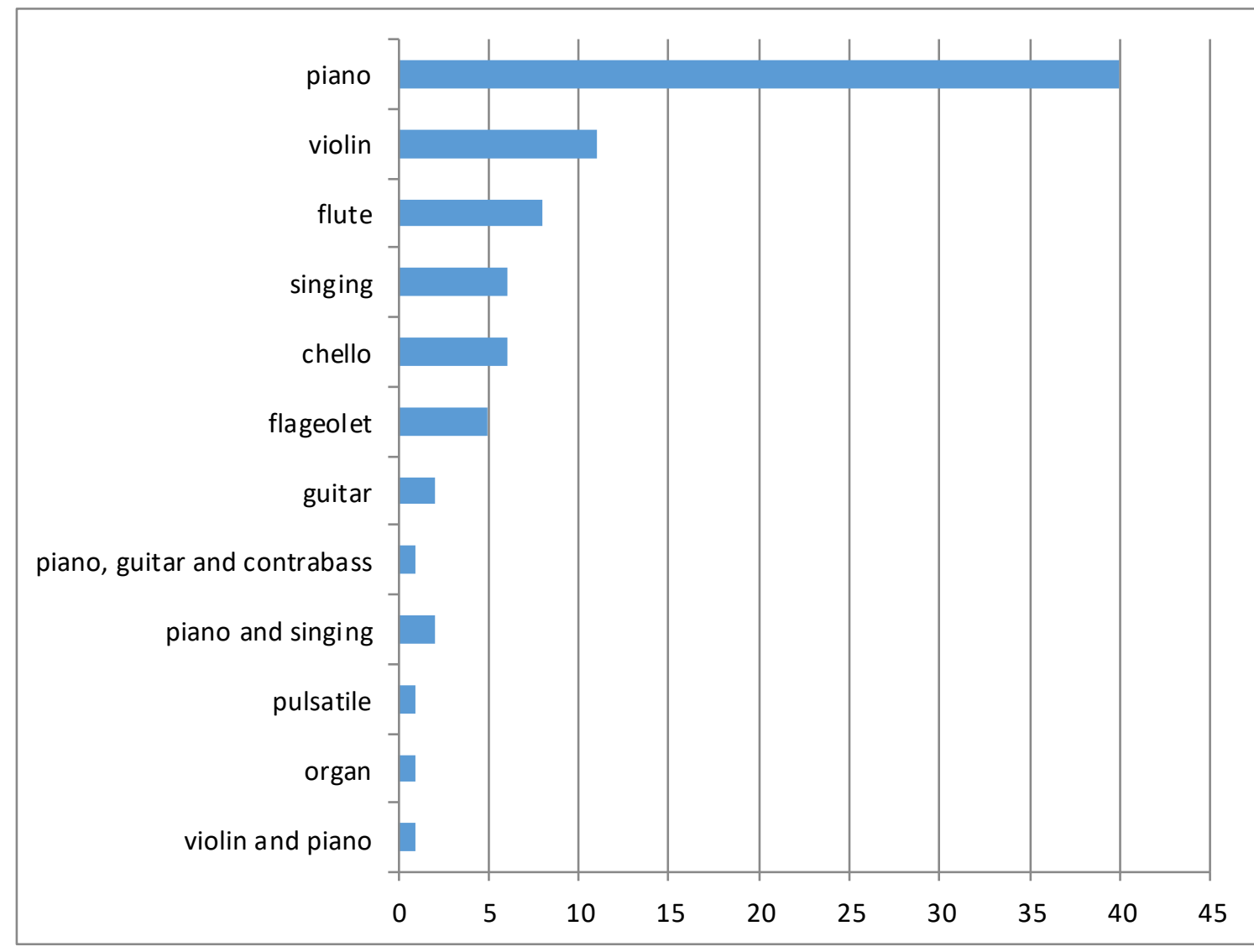

We also examined which background variants form the beginning age of studying instruments. We can see a peculiar picture in case of the mother's qualification and the beginning of learning music. We found that children of mothers with university or college qualifications start learning music earlier (under 8) while children of mothers with vocational high school qualification start at the age of 12 . We can associate a higher level of sociocultural background to higher educational qualification that creates the conditions of learning music with greater probability. In case of the mothers with vocational high school qualifications there can be a lack of this background or the prestige of learning music. 
Figure 4. Correlation between the mother's qualification and the age of starting learning music (Foreign Language Interpretation Database, $\mathrm{N}=90$, given in age)

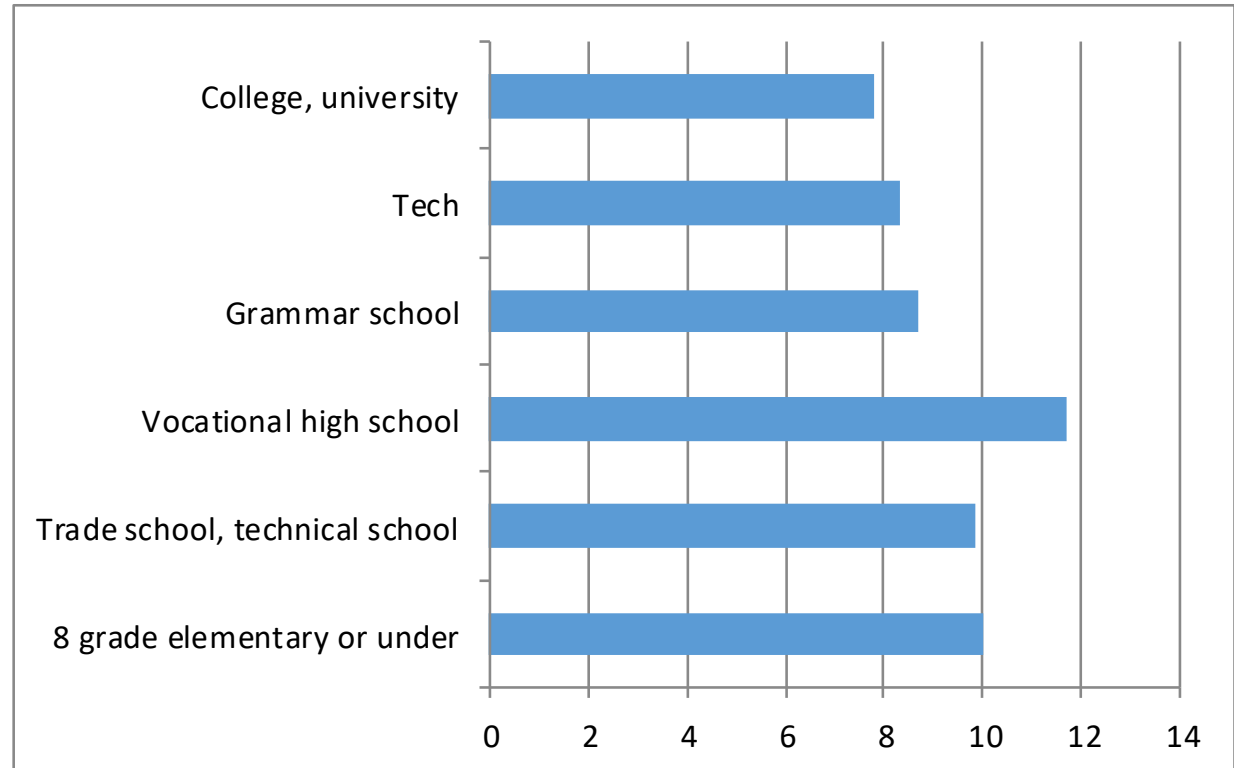

There is further significant correlation between the type of settlement and the starting of learning music. The earliest - around 8 years old children living in smaller towns - are the ones starting learning music, while the starting point of learning music for children from villages or farms is 12 years old. We see that the group of students coming form villages or farms started their music studies later as well. We claim that the reason for that is in the lack of infrastructure of musical education, too. At the same time, it can be observable that children from smaller towns start earlier than those from county seats or even from the capital. In our opinion, in the background we can find either the wish to follow the social groups with higher status or the more personal relational net of the institutions of smaller settlements.

Figure 5. Correlation between the type of settlement and the starting of learning music (Foreign Language Interpretation Database, $\mathrm{N}=90$ given in age)

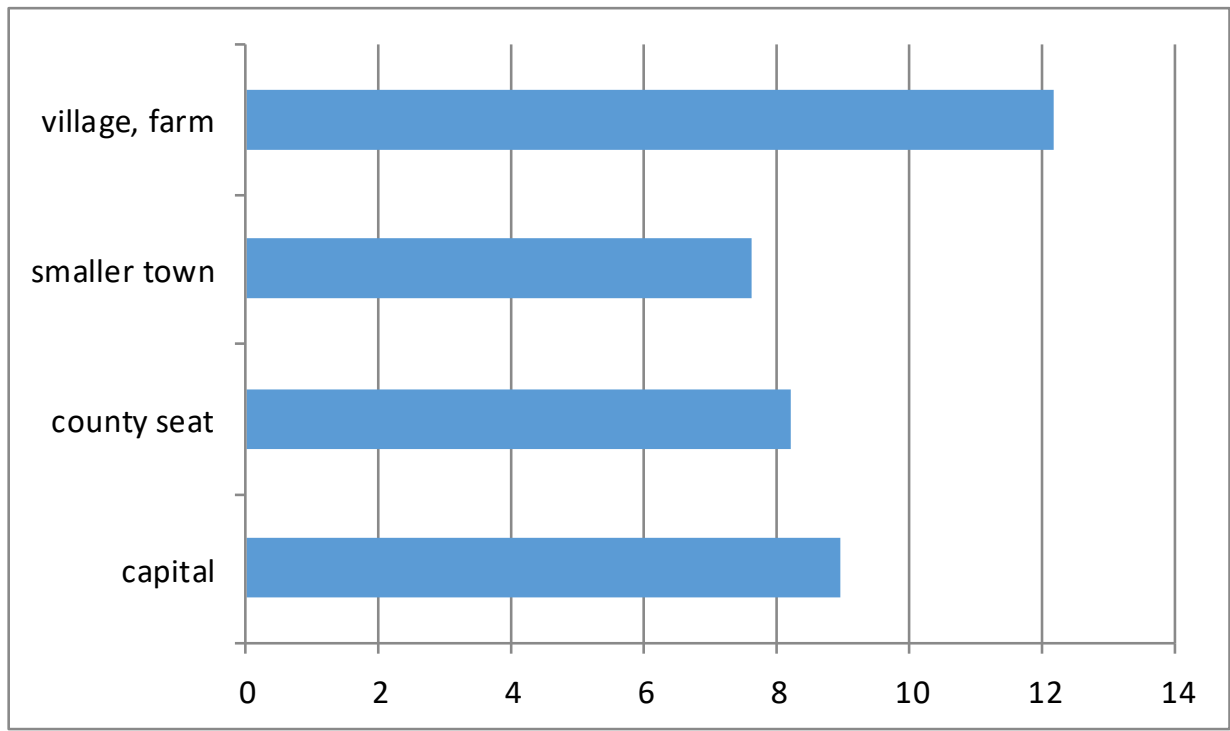


We also asked students whether there is anyone who pursues music. $51,1 \%$ of the families have other musicians and $44,4 \%$ do not. Music in family, therfore cannot be regarded as an unambigous fact for career orientation.

\section{Linguistic proficiency}

In the third group of questions we wanted to get a picture of the language training of soloist students. With regards to the studied languages it is clear from Figure 6. that English is the priority language. English was never learnt by only 6 students. There were 72 studying German, 76 Italian, French 22, Russian 17 and Spanish 10. We tie the high study rate of German and Italian to the fact that most of the vocal literature were written in these languages. These language study data correspond to those of the national measurment results (Veroszta, 2016), which say that students in higher education of art art and art mediation training with basic knowledge of English (98,5\%) and French (25,3\%) goes beyond the national average $(94,8 \%$ and $18 \%)$ in languages.

Figure 6. Most often studied foreign languages (Foreign Language Interpretation Database, $\mathrm{N}=90$ given in percentages)

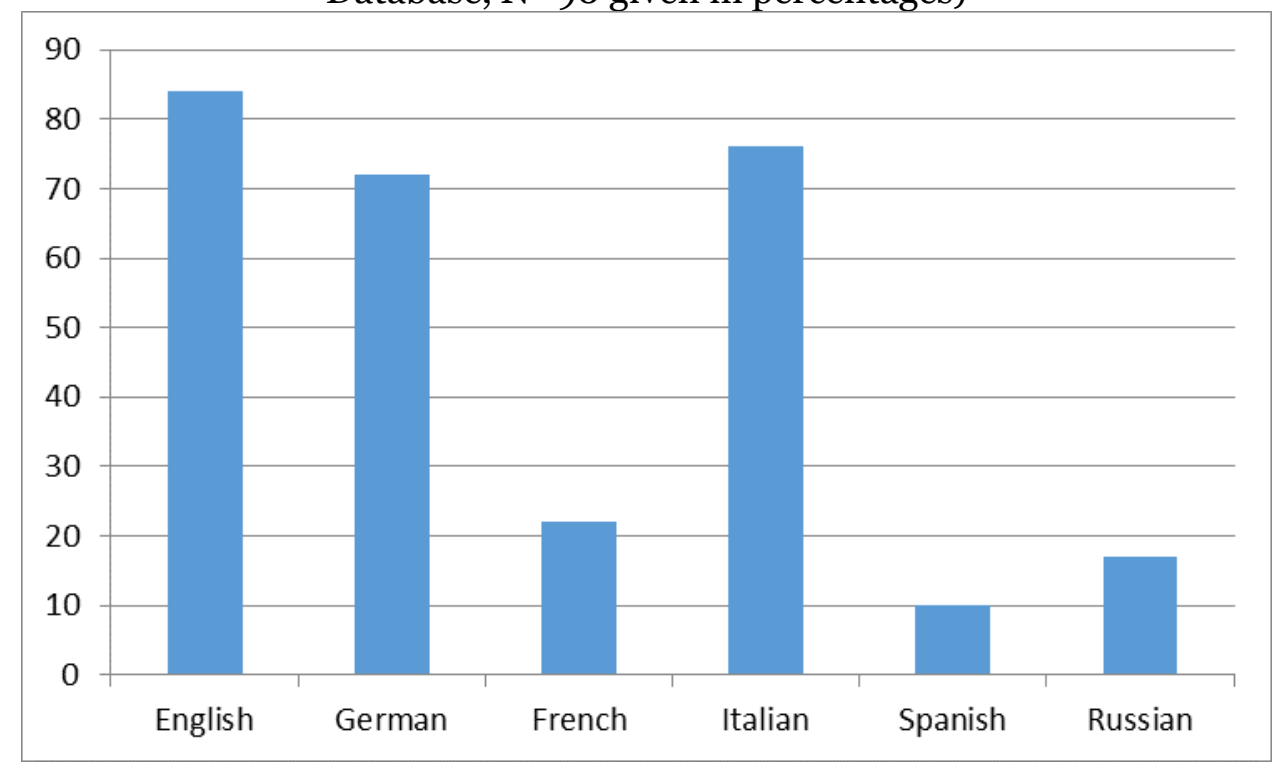

The time period of language studying shows a particular form in comparing languages. In Figure 7 . we can see that the respondant students spent the longest time learning English (58,3\%) and German (36,1\%). There are 5, 9\% of students who studied Russian for more than 7 years and only $1,3 \%$ of them said that they had studied Italian for at least 7 years. Noone studied French and Spanish this long. In the 4-6 year interval, studied languages show a square picture, most students studied French $(31,8 \%)$ the fewest studied Russian $(17,6 \%)$ for this long. It is also graphic that langauges often used in vocal literature, like French, Italian, Spanish and Russian were studied for less than 3 years. 
Figure 7. Length of language studies in comparison of languages (Foreign Language Interpretation Database, $\mathrm{N}=90$ given in percentages)

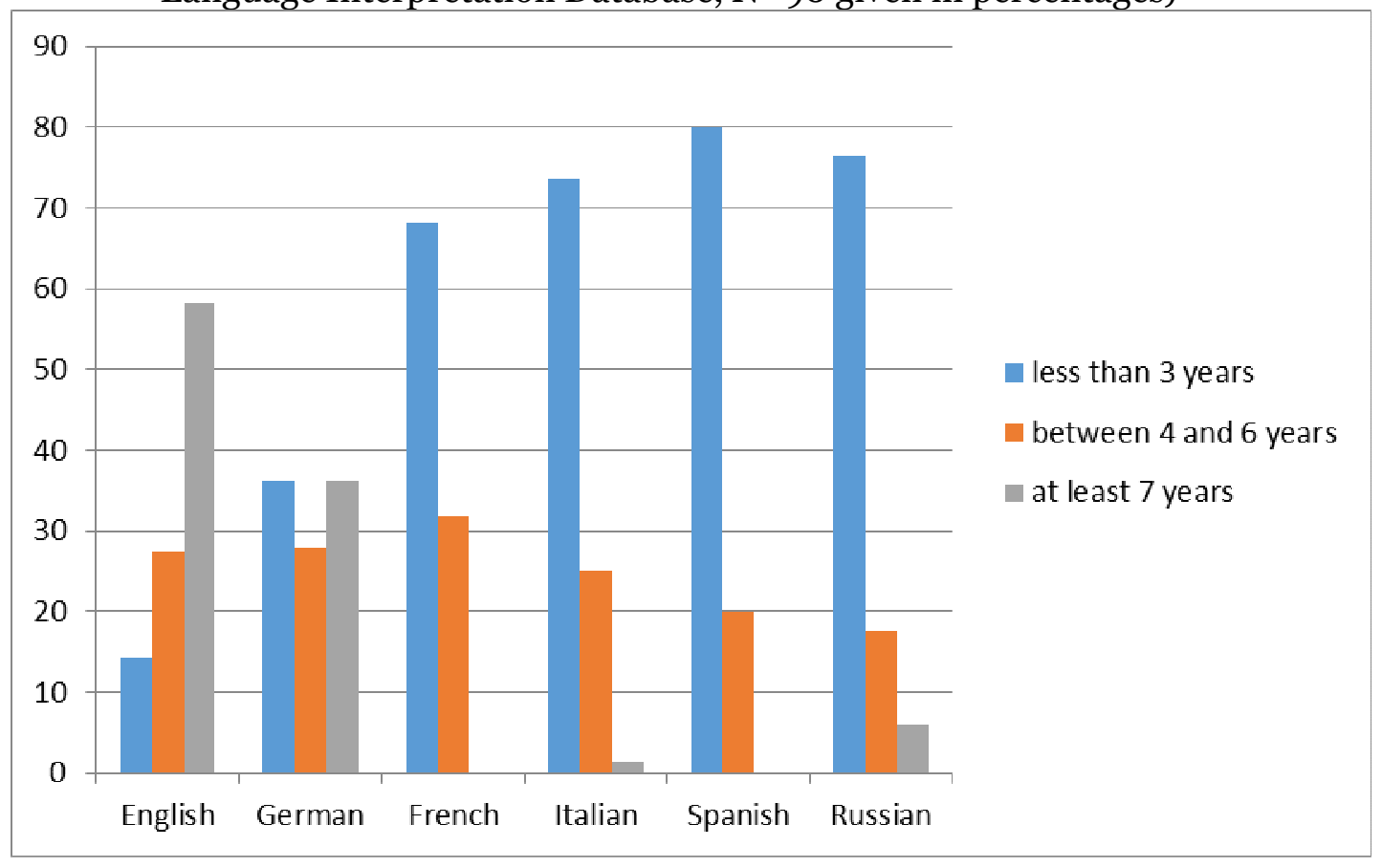

These data let us conclude that studying languages used in singing gets into the foreground during the higher education training while the aquisition of knowledge of English can be placed to earlier years.

We continued the studying of languages mostly used in vocal interpretation with the questioning the level of their command of language. Firstly, we were curious to see how students judge their own command of language. We put the results in Figure 8. showing that most students judge their command of English and German as intermediate and advanced level as well. Everyone thought of their command of Russian as elementary and they claimed advanced level of command of language only in cases of German (75) and Italian (25). 15\% of students know French in intermediate level, $7 \%$ are intermediate in Italian and $23 \%$ of them are intermediate in Spanish according to their own judgement. 
Figure 8. Level of command of language according to personal judgement (Foreign Language Interpretation Database, $\mathrm{N}=83, \mathrm{~N}=65, \mathrm{~N}=14, \mathrm{~N}=64, \mathrm{~N}=6$, $\mathrm{N}=9$, given in percentages)

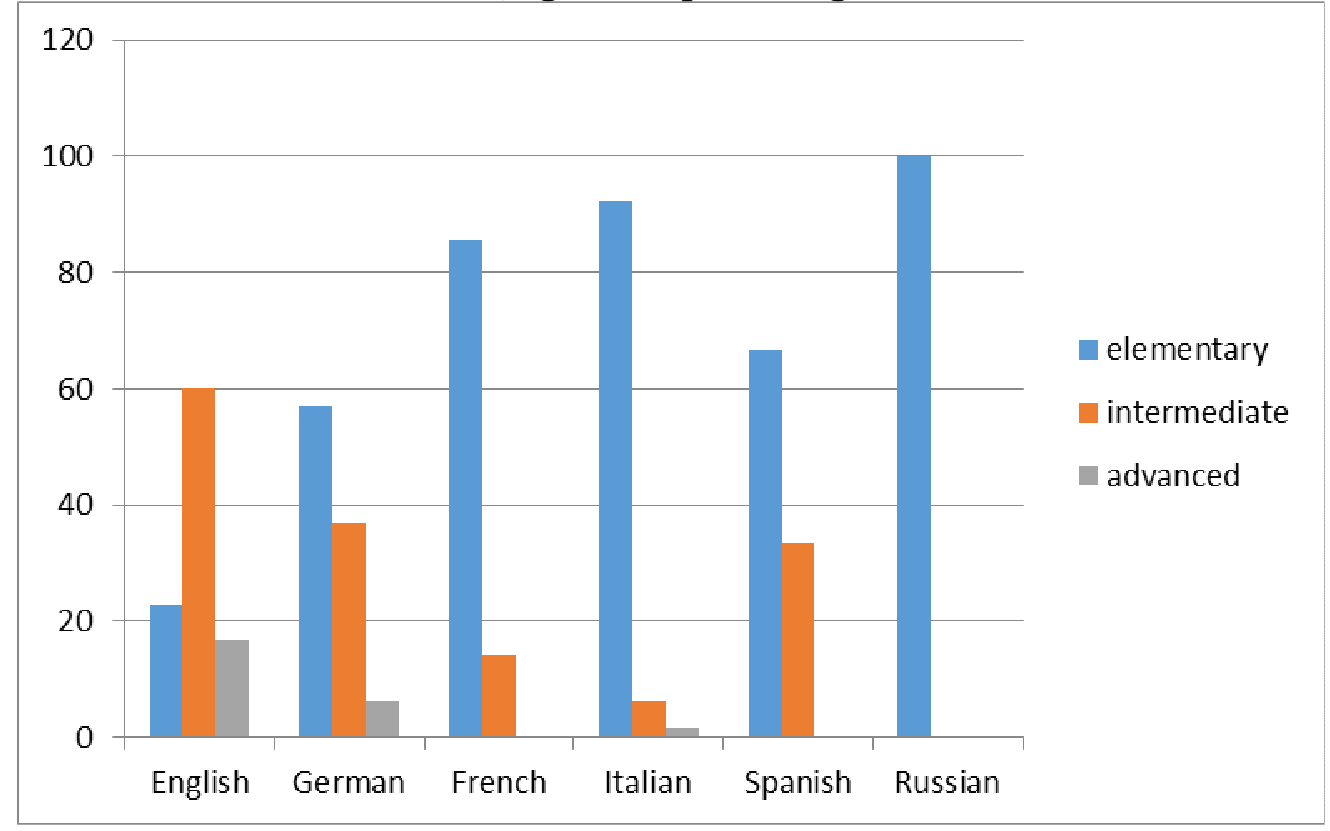

For the correlation of other variants of command of language, we have created an index. The respondants had to judge their own level of language out of six languages. Advanced level knowledge valued 3 points for a language, intermediate 2 points and elementary level 1 point. We estimated the students' command of language with the help of this index. The average index of this command of language became 4,33. This means that students know at least 2 languages in intermediate level or they have an advanced and an intermediate level command of language. With the help of the derivated index we could also compare the command of language with other background variants. The low number of elements did not give us the opportunity to draw significant conclusions about the differences but with regards to the economic capital there is a remarkable line showing the relationship between the economic capital and command of language. The high economic capital value has the highest command of language: 4,6 . 
Figure 10. The index values of command of language in relation to the economic capital. (Foreign Language Interpretation Database, $\mathrm{N}=90$ )

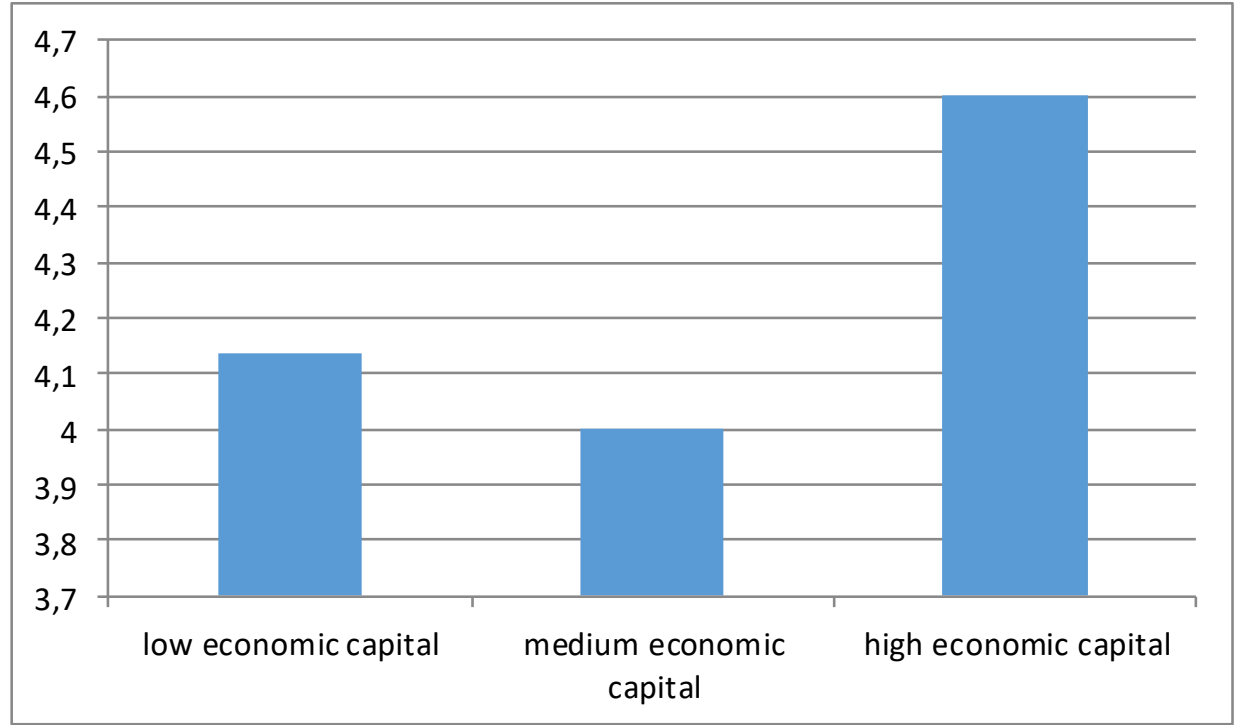

The level of command of language was measured with questions about the levels and types of language exams. We derivated another index from the exams gained from the studied languages in a way, where advanced level exams valued 3 points, intermediate level exam got 2 points and elementary level exam got 1 point. The received value of this showed a much worse result as opposed to the index of the command of language. The average value of the students' pattern was 1,89 , which is a remarkable value by itself as well. This value indicates that an average number of students do not have intermediate exam in any languages. The discrepancy of the language exam index and the index of command of language on personal judgement raises questions of the efficiency of language learning. Researches made in 2015 with freshly graduated students form higher education showed that the latesome degree was caused by the language exam by $70 \%$ of the cases. On the basis of art and science field distribution, the rate of retained degrees in the art and art mediation trainings are even higher, 76,3\% (Veroszta, 2016).

$30 \%$ of our sample do not have intermediate language exam, in case of BA students the rate is higher, $36,2 \%$. The index of language exams of students in undergraduate training is higher $(1,85)$ that can be explained with the urgency of getting a language exam that the respondants feel toward the end of their training cycle as opposed to those students who are in the earlier years of undivided training programme. The higher index of MA students can come form their age and longer time period spent with language learnin. Our research did not give us the opportunity of getting a precise picture of when MA students got their language exams during their training period. However, we think it is important to note that it is not compulsory to get a second language exam in the soloist MA higher education.

We thought it important to explore the connection between language proficiency and demographical background as well. In comparison of the language exam index and type of settlement we found that students from the capital have the highest language exam index, while students living in 
county seats have the lowest language exam index. This can be explained with the infrastructural background of language learning is richer in the capital as far as institutions and private learning are concerned. In case of students from villages and farms it is remarkable that their command of language is not behind from that of the town dwellers. Probably it is because they had their secondary studies in grammar school or vocational high school (Figue 11.)

Figure 11. The value of the language exam index in relation to type of settlements (Foreign Language Interpretation Database, $\mathrm{N}=90$ )

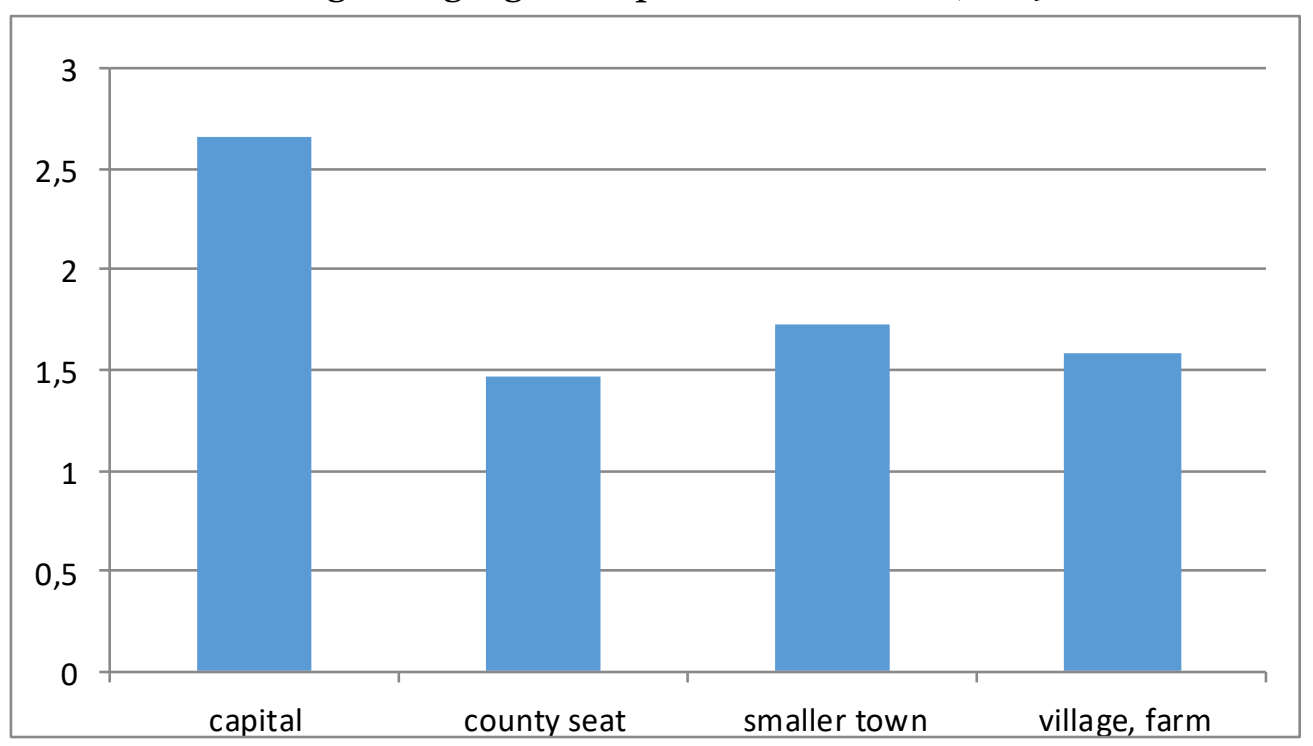

The research of foreign language proficiency of solois students gains meaning in its relation to the application of language. As a part of the questionnare, we asked the students about the aims and ways they use the foreign languages. In Figure 12. it is clear that the main application of the language is singing in the foreign language which was marked by $90 \%$ of the students. After that the use of Internet and listening to foreign language music came. Written or oral communication in the foreign language is not typical for even $60 \%$ of the students either. 
Figure 12. Application of foreign languages (Foreign Language Interpretation Database, $\mathrm{N}=90$, given in percentages)

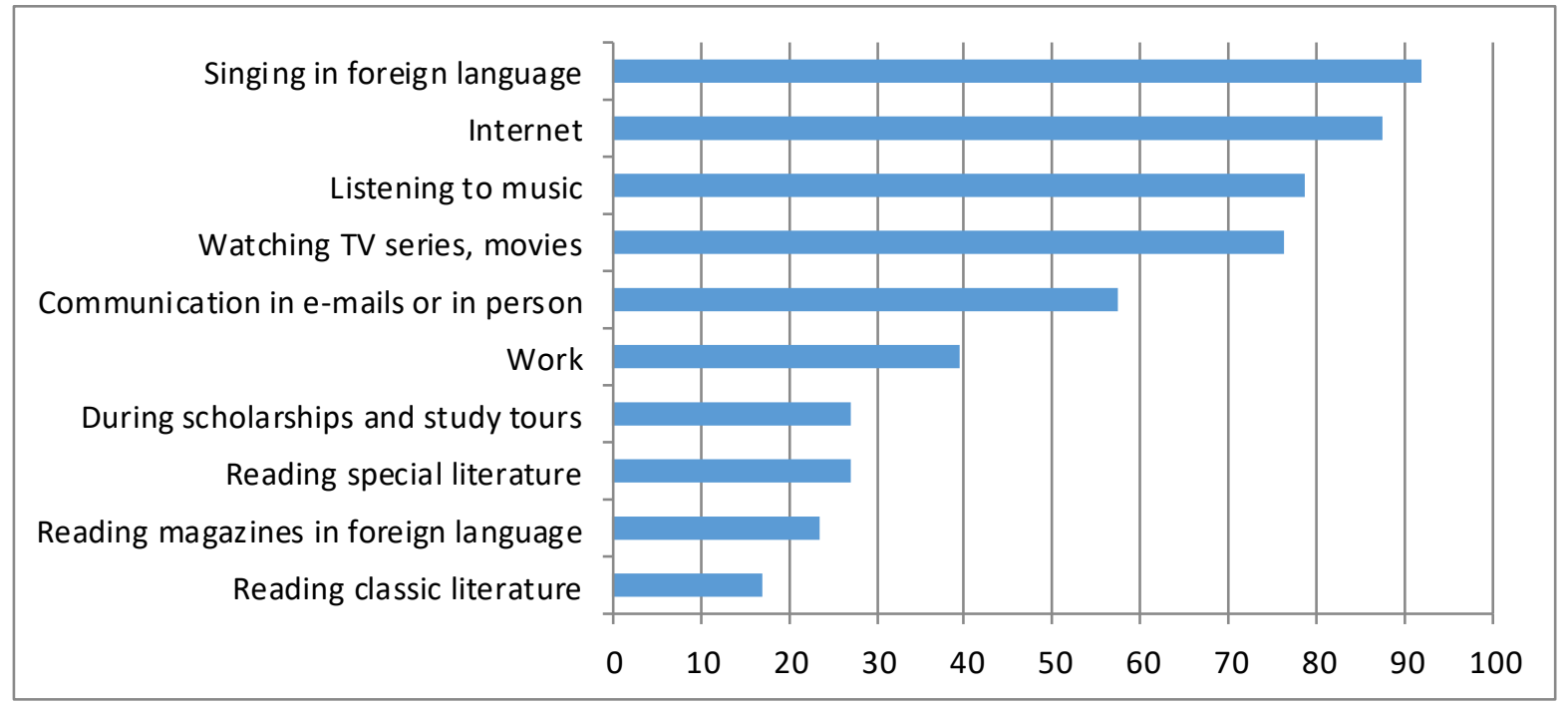

For a thorough mapping of the application of language we had questions about the curriculum frameworks. From the answers given we can say that most of the students $(95,3 \%)$ use the foreign language in the lessons of the main subjects and there is a smaller rate for chamber singing $(82,6 \%)$ and singing practice $(80,2 \%)$. Our assumption that during their studies of foreign languages they apply their prevailing knowledge a great deal was not justified, only $31,8 \%$ of the students claimed that they take advantage of their previous studies from other languages.

After looking at the language proficiency of the soloist students and where they apply the language it was a valid concern to research the institutional conditions of language training as well. We first examined the languages that are represented most in the vocal representation in Figure 13. Institutional studies of Italian $(44,4 \%)$ and German $(28,9 \%)$ have the highest rates, it is $4,4 \%$ in Russian and there is noone in French and Spanish. Tis rate is justified in case of Italian and German buti $\mathrm{n}$ casse of French and Russian - reagrding the composition of languages of the vocal literature - is extremely low. (Figure 13.) 
Figure 13. Institutional studies of foreign languages used in singing Foreign Language Interpretation Database, $\mathrm{N}=90$, given in percentages)

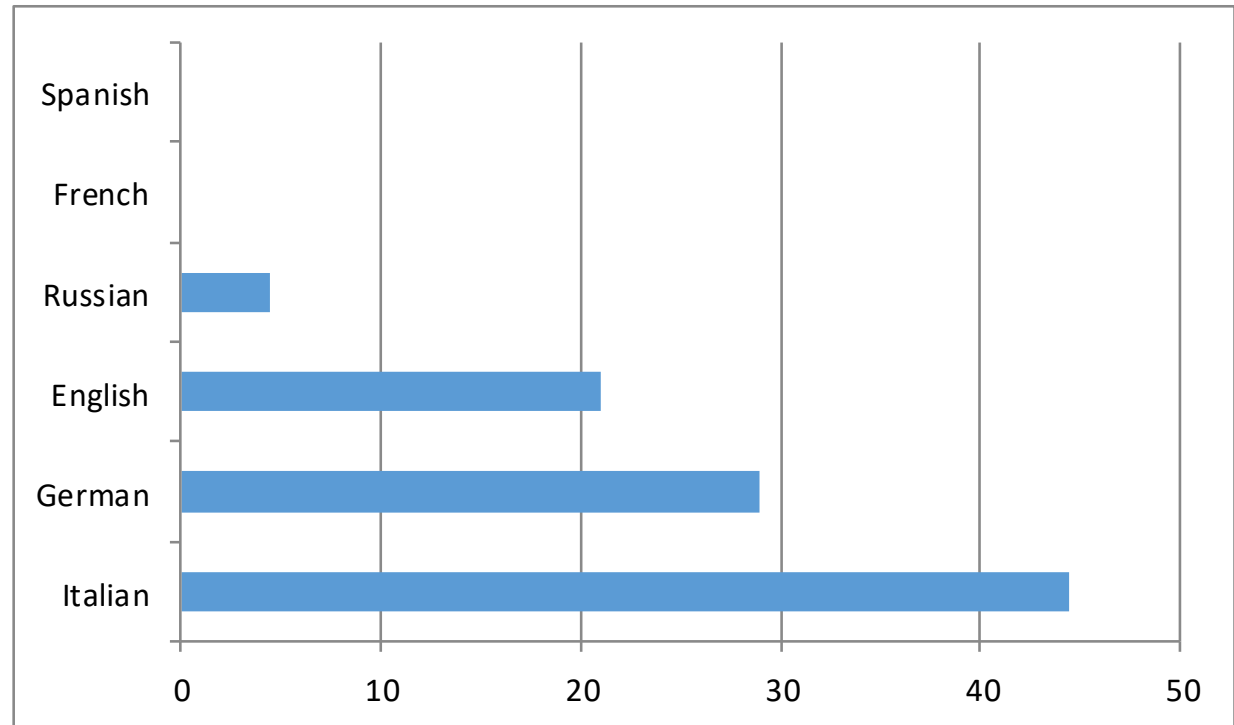

If we look at the languages that the students sing in during their studies, we find that they sing in Italian nand German with 30\%-30\% frequency. $35 \%$ of the students sing in Spanish, 24\% in Russian and 28\% in French. These rates put the distribution of languages of institutional language education in a peculiar light, showing a confliction between language training and expectations of interpretation.

\section{Conclusion}

The results of our research unequivocally justified that the demographical and sociocultural background of soloist students significantly affect the possibilities of learning music and languages. Students from smaller settlements start learning music later than those from the capital and they have more modest opportunities for language learning. Students from the capital have the highest rate of having language exams and the higher economical status demonstrates well how it differentiates the possession of a language exam. About the subject-matter and formal elements of the language training we concluded that there is not necessarily an automatic correlation between a higher qualification level and a longer language training; getting the second language exam is not neccessarily part of the MA training. Strong differences between the students' judgement of their own command of language and efficiency measurable with language exams indicate the gaps of efficiency of institutional language learning. English language as far as language preparedness of soloist students is in accordance with the national measures of the art training, however, this can be regarded sufficient only for the everyday communication and getting information from the special literature in case of soloist students. Institutional teaching of the languages of the mostly applied languages of vocal literature do not satisfy the expectations in vocal interpretation in original languages which is required from the students in creating their 
repertoire. Besides language lessons special interpretation courses are indispensable elements of perfection of singing in foreign languages.

\section{References}

Bocsi, V., Csercsa Zs, Csobay V., Karmacsi, K., Kőszegi I., Kreidl E. \& Pálfi R. (2017). Az egyetem peremén. A Debreceni Egyetem Gyermeknevelési és Felnőttképzési Karának szociokulturális összetétele. Különleges Bánásmód. 3(1). Megjelenés alatt. Retrived from http://old.gyfk.unideb.hu/kulonlegesbanasmod/index.html. ISSN 2498-5368

Duffek, M. (2009). Bizonytalan bizonytalanságok... Helyzetkép az átalakuló magyar zenei felsőoktatásról. In: Szilágyi Zs. (szerk.): Zeneoktatásunk. Argumentum Kiadó, Budapest

Garai, O. \& Kiss. L. (2014). Eurostudent V. - magyarországi eredmények. In: Kiss, L. (ed). A felsőoktatás szociális dimenziója. A Eurostudent V. magyarországi eredményei. Budapest: Educatio Társadalmi Szolgáltató Nonprofit Kft. 5-26.

Gifford, P. Owen (1960). The singer and foreign languages. University Washington, D.C., Washington

Veroszta, Zs. (2016). Frissdiplomások 2015. Budapest: Oktatási Hivatal Felsőoktatási Elemzési Főosztály.

??????????????????????????????????????????? I1. https://www.ksh.hu/docs/hun/xstadat/xstadat eves/i zoioo8.html The date of the download: 09.10.2017. 